\title{
Risk Disclosure: Empirical Investigation of UAE Companies' Compliance with International Accounting Standards
}

\author{
Sawsan Saadi Halbouni ${ }^{1} \&$ Asifa Yasin ${ }^{1}$ \\ ${ }^{1}$ Canadian University Dubai, Department of Accounting and Finance, United Arab Emirates \\ Correspondence: Sawsan Saadi Halbouni, Canadian University Dubai, Department of Accounting and Finance, \\ United Arab Emirates. E-mail: sawsan.halbouni@cud.ac.ae
}

Received: April 21, 2016

Accepted: May 30, 2016

Online Published: July 18, 2016

doi:10.5539/ijbm.v11n8p134

URL: http://dx.doi.org/10.5539/ijbm.v11n8p134

\begin{abstract}
This paper empirically investigates the degree of compliance with International Accounting Standards (IAS 21) Foreign Currencies Translation, which is a proxy for risk disclosure by public companies in the United Arab Emirates (UAE). The current study also examines potential factors, which might be affecting risk disclosure through utilizing IAS 21 voluntary disclosure indicator checklist to find risk disclosure by 52 companies listed on UAE stock markets for 2011 and 2012. In addition, regression analysis tests are applied to determine factors affecting risk disclosure. The results indicate a low level of risk disclosure demonstrated by companies understudy, a significant impact of business type on risk disclosure, and a negative significant impact of company age on risk disclosure. Furthermore, the results show that size, profitability, type of audit firm, and liquidity, they all had insignificant impact on risk disclosure as to the UAE sample understudy. In general, the findings show a low degree of compliance with IAS 21 Foreign Currency Translation by companies in the UAE, suggesting a serious overseers' intervention and corporate governance to guarantee quality financial reporting produced by UAE-listed firms.
\end{abstract}

Keywords: United Arab Emirates, risk disclosure, IAS 21, foreign currency translation

Paper type: Research Paper

\section{Introduction}

The increase in corporate scandals has caused lack of confidence among investors and creditors in companies' financial reporting (Ismail \& Abdul Rahman, 2011). To deal with this issue, the transformation of corporate governance is considered as the top priority among companies facing uncertainty and bankruptcies (Raber, 2003). Watson and Head (1998, p. 192) defined risk as "referring to a set of outcomes arising from a decision that can be assigned probabilities, whereas "uncertainty" arises when probabilities cannot be assigned to the set of outcomes". According to Linsley and Shrives (2006), risk disclosures is about informing the users of accounting information about any threat which may affect or has already affected the organization or its management.

Linsley and Shrives $(2000,2005,2006)$ argued that the main advantage of risk disclosure by companies is the reduction in the cost of capital resulted from removal of the embedded in the cost of capital to cover for uncertainty associated with the firm's risk status (Linsley \& Shrives, 2006).

On the one hand, Hakansson (1981), Diamond (1985), Verrecchia (1990), and Marshall and Weetman (2007) confirmed that disclosure serve for the interest of the investors through reducing the cost of obtaining the information, while at the same time, reduce the benefits for individuals having information advantage. Marshall and Weetman (2007) added that the reduction in the information cost has a positive impact on the firm stock liquidity. Hassan $(2009,2011)$ believed that corporate managers preferred voluntary disclosures to show their managerial skills and avoid any misinterpretation of their performance. On the other hand, Marshall and Weetman (2007) revealed that an information gap is expected to exist between managers and users when the disclosure level in relevant information in the finial reports is very low, and consequently, lack of transparency.

Because of various voluntary requirements to disclose risk-related information, such as the International Financial Reporting Standards' (IFRS), International Accounting Standards (IAS) 21 Foreign Currency Translation, corporate managers are motivated to disclose risk in the accounting information for the purpose of signaling and influencing the firm's stock prices. 
In view of the fact that UAE has been promoting a more open economic environment recently, accessible for both local and international investments in order to nurture more solid and profitable business possibilities, the Central Bank of the UAE in 1999, required all financial institutions operating in the UAE to develop their financial reports in compliance with International Accounting Standards (IAS). Moreover, Federal Law No. 4 of 2000, empower the authority to set proper regulations to govern Securities Markets through establishing the UAE Securities and Commodities Authority (Halbouni, 2009). Today, Law No. 2 issued in 2015, and recently enforced by July 2015 demands that all UAE-companies incorporate IAS standards when preparing financial information (IFRS, 2015).

In emerging economies, Shleifer and Vishny (1997) argued that in general, corporate governance are generally not strongly practiced because of the lack of transparency and limited information disclosed about corporations (Mimba et al., 2007). Therefore, the importance of disclosing more information to the public has been given more attention (Maines et al., 2002; Coy \& Dixon, 2004; Hassan, 2011). In addition, compliance with IAS 21 voluntary disclosure requirements informs different stakeholder about corporations' characteristics, such as company size, profitability, liquidity, leverage, company age, audit type, and business type.

The main purpose of this study is to investigate the degree of compliance with IAS 21 by UAE-listed companies. To do that, the current research seeks to answer the following two research questions. First, to what extent do corporations in the UAE comply with IAS 21 Foreign Currency Translation (a proxy for risk disclosure)? Second, what factors are affecting UAE companies' degree of risk disclosure (compliance with ISA 21)? This study contributes to the corporate governance literature by examining risk disclosure, which is among the governance overseers' obligations to improve the quality of accounting information produced by companies in the UAE.

The coming sections of this paper is structured as follows. Section 2 covers the salient literature and hypothesis development. Section 3 describes the study's research design and data collection. Section 4 presents the empirical results and analyses. Section 5 offers a supplementary discussion, describes the limitations of the study, identifies avenues for future research, and offers some concluding remarks.

\section{Literature Review and Hypothesis Development}

\subsection{Risk Disclosure -Degree of Compliance with IAS 21}

Foreign currency transaction (IAS, 2011) refers to an economic event (buying and selling goods or services, borrowing and lending money, depositing assets, or settling liabilities), that requires settlement in a currency other than the local currency of the country in which the financial institution or bank is located. While translation of foreign currencies involves converting accounting numbers from one currency into another currency for financial reporting purposes, Huang and Vlady (2012) suggest that corporations can either convert foreign currency from international trade in financial reports, or translate foreign operations and currencies in order to prepare consolidated financial reports.

Collins and Salatka (1993), Louis (2003), and Pinto (2005) argued that there have been major controversies in the past few decades resulting from the translation of foreign currency. Moreover, the recent global financial crisis has significantly raised research interest in corporate risk management and disclosure around the world and triggered regulatory reforms and responses from various government agencies and accounting standards setters (Dobler et al., 2011). The authors added that the lack of transparency and clarity in risk disclosure and the increasing complexity of business supported by constantly improving information technologies have created a need to conduct more research in accounting and related fields to study how listed companies disclose information about their risk profiles, tolerance levels, risk management, and monitoring processes.

Hassan (2009, p. 669) defined corporate risk disclosure as "the financial statements inclusion of information about managers' estimates, judgments, reliance on market-based accounting policies such as impairment, derivative hedging, financial instruments, and fair value as well as the disclosure of concentrated operations, non-financial information about corporations' plans, recruiting strategy, and other operational, economic, political and financial risks." Elbannan and Elbannan (2015) indicate that risk disclosures include information published within the annual report to provide both qualitative and quantitative information about uncertainties facing an economic entity, such as credit, interest rate, liquidity, and market risk. They added that disclosure helps market participants assess the amount, timing, and risk related to their investments. Emm et al. (2007) argued that increasing the ability of the company to have an access to capital markets, enhancing the attractiveness of the company's shares to investors by reducing the costs of information gathering, increasing the liquidity of the company's securities, and reducing the cost of raising capital are the main advantages of risk disclosure. Berger and Hahn (2003) confirmed the argument that risk disclosure is a choice variable set by management in spite of being mandatory. 
Based on this literature review, to investigate the degree of compliance with risk disclosure, the current study analyzes the degree of compliance with IAS 21, a proxy for risk disclosure for each company in the study, by dividing the actual scores achieved by the maximum number of applicable disclosure for both 2011 and 2012.

\subsection{Identifying Influences on Companies' Degree of Risk Disclosure}

Several reasons might explain the possible association between the quality of financial report disclosure and a company's characteristics, as outlined in Singhvi and Desai (1971), Jensen and Meckling (1976), Firth (1979, 1984), Chow and Wong-Boren (1987), Cooke (1991 \& 1992), Hossain et al. (1994), Meek et al. (1995), Watson et al. (2002), Akhtaruddin (2005), Abraham and Cox (2007), and Souissi and Khlif (2012).

The literature on accounting policy choice suggests many variables may affect company risk disclosure. Popova (2013) pointed out that disclosure is twofold. According to that study, mandatory disclosure occurs when disclosing certain elements of information is required by regulations, while voluntary disclosure occurs when the disclosure of more information than required because of the interest of the company, such as improving the reputation of the company, reducing political and regulation intervention in addition to enhancing the stock liquidity (Entwistle, 1997). Firth (1979), Owusu-Ansah (1998), Gray and Roberts (1991), Watson et al. (2002), and Souissi and Khlif (2012) argued that large firms are generally more visible and have greater social power than small ones. Therefore, the current study expects the degree of compliance with IAS 21 and consequently, risk disclosure by large companies (measured in terms of total assets and total revenues) to be greater than that by small companies.

With regard to profitability, signaling theory states that companies with "good news" due to better performance are more likely to disclose more detailed information than by "bad news" in order to avoid undervaluation of their shares (Inchausti, 1997). Cerf (1961) and Singhvi and Desai (1971) believed that profitability is an indication to the performance of management, therefore, managers of profitable companies are more likely to disclose information than those with negative performance to support the continuance of their positions and performance-related compensatory schemes that may be due to them.

According to the earnings-signaling hypothesis, the market reacts favorably to earnings (Yedo \& Ziebart, 1995). They added that, since return on assets (ROA) and return on equity (ROE) are generally associated with favorable management performance, the market appropriately interprets them in addition to the current ratio as a measure of liquidity as a management signal of favorable future performance. ROA can be defined as the ratio of net profits to net assets. This rate accordingly can reflect the disclosure level by a company. Benston (1973) argued that management has the incentive to disclose more reliable financial information based on the IAS requirements in order to support its position and compensation when the ROA is high in a company. Owusu-Ansah (1998) argued that unprofitable companies would be inclined to release more information in defense of poor performance. This research expected that the more profitable a company is, the greater is its consistency with IAS 21 disclosure requirements

Leverage, as the ratio of debt to equity, can be considered a measure of risk. Agency theory indicates that the firm is a connection for a set of contracting relationships among individuals (Jensen \& Meckling, 1976). This study expects that the management of strong companies, measured by low leverage (debt/equity ratio), would be able to produce reliable financial information and therefore, be more compliant with the disclosure requirements of IAS, and vice versa, that is, the management of weak companies with a high debt/equity ratio would not be able to produce reliable financial information and therefore, would be less likely to be compliant with voluntary disclosure of IAS 21.

Company age is another critical factor affecting the degree of corporate disclosure (Popova et al. 2013). They argued that managers of companies with long experience resulted from its age are inclined to disclose more information to enhance the reputation and the image of the company in the market. Owusu-Ansah (1998) argued that younger companies might suffer from competitive disadvantage and thus, they disclose more information. They added that the cost of gathering, processing, and disseminating the required information might be a burden for younger companies.

In addition, type of audit firm is expected to influence the degree of compliance with the IAS 21 requirements. According to Bradbury (1990), auditing as a monitoring mechanism, provides assurance about the quality of information reported between principal and agent. Therefore, the current study expects that those auditors with strong reputations, such as the "Big Four" firms, are more likely to be associated with clients disclosing high levels of information in their published financial reports (Chow, 1982; Watts \& Zimmerman, 1986).

To answer the second research question about factors that affect UAE companies' degree of compliance with 
IAS 21, the current study expects that company size (total assets and total revenues), profitability (ROA and ROE), leverage (debt/equity), liquidity (current ratio), company age, type of auditor, and business type have significant impacts on the degree of compliance with IAS 21 voluntary disclosure requirements and consequently, risk disclosure.

The following is the main research hypothesis.

H1: A higher degree of compliance with IAS 21 Foreign Currency Translation voluntary disclosure requirements is significantly affected by total assets, total revenues, ROA, ROE, current ratio, leverage, company age, audit type, and business type.

\section{Research Design and Data Collection}

The study relies on a sample of 52 corporations listed on either the Dubai Financial Market or the Abu Dubai Securities Market. The sample population is classified as follows: 10 real estate companies, 4 transportation companies, 15 industrial companies, 10 consumer staples companies, 6 telecommunication companies 5 service companies, and 2 energy companies. All financial institution and insurance companies were excluded because they are subject to specific disclosure requirements, such as those required by the Central Bank, and thus, their annual reports are not considered as voluntary. The study utilizes a checklist of IAS 21 voluntary disclosure indicators (Deloitte \& Touch, 2007). The study crosschecks the checklist against UAE companies' annual reports of 2011 and 2012. The annual report for each company is carefully scrutinized against the checklist to identify the total score. A score of 1 is assigned when the disclosure item is disclosed in the financial report, while a score of 0 is assigned if the item is not disclosed or if it is not applicable. The degree of compliance for each company is calculated as the summation scores achieved by that company. The total compliance rate for each company is calculated by dividing the total number of disclosures achieved by the maximum number of applicable disclosures (Firth, 1980; Cook, 1992; Ahmad Nicholls, 1994; Hossain et al., 1994; Gray et al., 1995; Meek et al., 1995).

To find the overall degree of risk disclosure, the total scores achieved by all companies under the study, as measured by the individual checklist, were compared with the potential indicators of compliance, which equaled the number of IAS 21 items multiplied by the number of companies, that is the score that would have been recorded if every company had met every item. The actual compliance score was divided by the potential compliance figure, as proposed by Copeland and Frederick (1968).

In addition, for the purposes of answering the second research question and measuring the association between the UAE company's degree of risk disclosure and factors that might affect that level of disclosure, such as company size, ROA, ROE, current ratio, leverage, company age, audit type and business type, a regression analysis was conducted.

Scott (1997) argued that efficient market theory implies an important role for full disclosure, including disclosure of accounting policies. In this study, the following variables have been selected and used as the basis for testing factors affecting the degree of compliance with IAS 21 voluntary disclosure and consequently, risk disclosure by companies in the UAE: The conceptual relationship between the degree of compliance with the IAS 21 as a proxy for degree of disclosure DoD and the above mentioned variables is reflected in the following formula:

$$
\operatorname{DoDit}=\operatorname{fit}(\beta 0+\beta \mathrm{X} 1+\beta \mathrm{X} 2+\beta \mathrm{X} 3+\beta \mathrm{X} 4+\beta \mathrm{X} 5+\beta \mathrm{X} 6+\beta \mathrm{X} 7+\beta \mathrm{X} 8+\beta \mathrm{X9})
$$

Where:

$$
\begin{aligned}
& \text { DoDit }=\text { degree of disclosure } \\
& \mathrm{B} 0=\text { constant value } \\
& \mathrm{X} 1=\text { total assets } \\
& \mathrm{X} 2=\text { total revenue } \\
& \mathrm{X} 3=\text { ROA } \\
& \mathrm{X} 4=\text { ROE } \\
& \mathrm{X} 5=\text { leverage } \\
& \mathrm{X} 6=\text { liquidity } \\
& \mathrm{X} 7=\text { company age } \\
& \mathrm{X} 8=\text { audit firm } \\
& \mathrm{X} 9=\text { business type }
\end{aligned}
$$




\section{Empirical Results and Analyses}

\subsection{Characteristics of the Sample and Financial Measures}

Descriptive statistics covering the organization's background, type of business and audit firm, company age and size are presented in Table 1. Also reported in the same table are the summary statistics about companies' financial measures, including ROA, ROE, working capital and leverage.

As shown in Table 1, the research sample provides a reasonable representation of various types of companies in terms of business type (real estate, manufacturing, retail, and services companies) as well as the two types of auditors (Big Four or regional/local).

Table 1. Information on background of organizations

\begin{tabular}{|c|c|c|c|c|c|}
\hline Description & & & & No. $=$ & Percentage \\
\hline \multicolumn{6}{|l|}{ Business Type } \\
\hline & & Real Estate & & 10 & $19.2 \%$ \\
\hline & & Manufacturing & & 15 & $28.8 \%$ \\
\hline & & Retail & & 10 & $19.2 \%$ \\
\hline & & Service & & 17 & $32.8 \%$ \\
\hline & & Total & & 52 & $100 \%$ \\
\hline \multicolumn{6}{|l|}{ Audit Type } \\
\hline & & Big Four & & 36 & $69.2 \%$ \\
\hline & & Local or Regional & & 16 & $30.8 \%$ \\
\hline & & Total & & 52 & $100 \%$ \\
\hline & Total & $\begin{array}{l}\text { Minimum } \\
\text { (Dh. Millions) }\end{array}$ & $\begin{array}{l}\text { Maximum } \\
\text { (Dh. Millions) }\end{array}$ & Mean & SD. \\
\hline Total Assets & 104 & 19 & $11,500,000$ & 9,927 & $2.42572 \mathrm{E}+10$ \\
\hline Total Revenue & 104 & 0 & $3.37 \mathrm{E}+4$ & 2,997 & 7205604011 \\
\hline Company Age & 102 & 5 & 55 & 24.4 & 13.902 \\
\hline ROA & 104 & -.17 & .21 & .0296 & .072 \\
\hline ROE & 104 & -.66 & 2.68 & .082 & .331 \\
\hline Current Ratio & 104 & .13 & 246.3 & 5.72 & 26.57 \\
\hline Leverage & 104 & .00 & 10.07 & .806 & 1.38 \\
\hline
\end{tabular}

As shown in Table 1 above, summary statistics about the characteristics of companies indicates that $32.8 \%$ of the sample are service companies (four transportation; six telecommunication; five services, and two energy), while $28.8 \%$ are manufacturing companies. In addition, the results indicate that $69.2 \%$ of those companies are audited by an international audit firm (Big Four). The mean average of total assets is Dh. 9,927 million and the UAE companies' average age is 24.4 years. Furthermore, the table shows the minimum, maximum, mean, and standard deviation for some financial measures, such as ROA, ROE, total assets, total revenues, current ratio, and leverage. Table 1 shows that the research sample represents a reasonable spread over the two types of auditors (Big Four or local/regional), all types of business except financial institutions, size, age, and financial measures, in addition to different financial measures. Therefore, the findings should be seen as unbiased and reliable.

\subsection{Risk Disclosure-Degree of Compliance with IAS 21}

To answer the first research question about the extent to which companies in the UAE comply with the voluntary disclosure requirements of IAS 21 Foreign Currency Translation (a proxy for risk disclosure), risk disclosure has been calculated for each company in the sample by dividing the actual scores achieved by each company by the total number expected to be achieved by the companies for both 2011 and 2012. The results are shown in the following Table 2 . 
Table 2. Risk disclosure - degree of compliance with IAS 21

\begin{tabular}{llllll}
\hline Period & Total & Minimum & Maximum & Mean & SD. \\
\hline 2011 & 52 & .00 & .55 & .068 & .103 \\
2012 & 52 & .00 & .55 & .078 & .106 \\
Overall 2011 and 2012 & 104 & .00 & .55 & .073 & .104 \\
\hline
\end{tabular}

Table 2 indicates a very low level of risk disclosure by companies in the UAE. The table shows that the overall risk disclosure by UAE companies is $6.8 \%$ for 2011 and slightly improved to $7.8 \%$ for 2012 . In addition, Table 2 indicates that the minimum disclosure by companies in the UAE is $0 \%$, while the maximum disclosure by companies is 55\% for both 2011 and 2012 .

\subsection{Influencing Factors on Companies' Degree of Risk Disclosure}

To answer the second research question about factors affecting UAE companies' risk disclosure, a regression model was applied to investigate the causal relationship between types of audit firm, business type, company size, company age, ROA, ROE, current ratio, and leverage, as suggested by Firth (1979), Barako et al. (2006), Akhtaruddin (2005), Abraham and Cox (2007), and Hassan (2009). The dependent variable is risk disclosure by companies in the UAE for both 2011 and 2012. The following Table 3 shows the results.

Table 3 shows that business type $(t=2.90, p=.005)$ and company age $(t=-2.71, p=.008)$ have significant impacts on risk disclosure by companies in the UAE at a 5\% significance level. The negative t-value of company age indicates that risk disclosure by younger companies in the UAE is higher than that by old companies. In addition, Table 3 indicates that type of audit firm, company size, ROA, ROE, and liquidity have no significant impact on risk disclosure by companies in the UAE, and the t-value for these variables are not significant at the 5\% level. The table indicates that the model's adjusted R2 (coefficient of determination) is $9 \%$ (F-value $=2.11, \mathrm{p}=$ $<.005)$.

Table 3. Influencing factors on companies' degree of risk disclosure in the UAE

\begin{tabular}{lllll}
\hline Independent Variables & $\mathrm{B}$ & Beta & t-value & Sig. \\
\hline (Constant) & .060 & & 1.502 & .136 \\
B: Audit Firm & .011 & .048 & .433 & .666 \\
C: Business Type & .020 & .326 & 2.90 & $.005^{* *}$ \\
D: Company Size (Total Assets) & $3.7913 \mathrm{E}-13$ & .088 & .318 & .751 \\
E: Total Revenue & $2.769-\mathrm{E} 12$ & .191 & .703 & .484 \\
F: Company Age & -.002 & -.286 & -2.71 & $.008^{* *}$ \\
G: ROA & -.195 & -.135 & -.653 & .515 \\
H: ROE & -.016 & -.041 & -.195 &. .846 \\
I: Leverage & -.011 & -.144 & -1.08 & .283 \\
J: Liquidity (Current Ratio) & -.001 & -.176 & -1.78 & $.078^{*}$ \\
\hline
\end{tabular}

Notes. $\mathrm{R} 2=.171 ; \mathrm{F}$-value $=2.11(\mathrm{P}=0.0236) ;$ Adjusted $\mathrm{R} 2=0.090$; Dependent Variable: risk disclosure for 2011 and $2012 ; * *$ and

*represent correlation is significant at the .005 and .10 levels, respectively (2-tailed).

\section{Discussion and Conclusion}

This study investigates risk disclosure by UAE companies through measuring the degree of compliance with IAS 21 Foreign Currency Translation. The study utilizes the IAS 21 voluntary disclosure indicators checklist that incorporates 21 disclosure items against 52 UAE companies' annual reports to find risk disclosure for each company and the overall risk disclosure for 2011 and 2012. Moreover, a regression analysis is applied to investigate factors affecting risk disclosure by companies in the UAE, such as company size (total assets and total revenues), profitability (ROA and ROE), liquidity (current ratio), leverage (total debt over total equity), company age, audit type, and business type.

The results reveal that UAE companies have a low level of compliance with IAS 21, a proxy for risk disclosure. The finding of the low level of risk disclosure by companies in the UAE is in accordance with findings obtained by Al Shammari (2014) in Kuwait. The current study's results confirm Aerts' (2005) argument that risk disclosure for different countries is subject to cultural influences. However, Hassan (2011) pointed out that the UAE's incentive to generate more opportunities for growth and financing through being opened and gaining 
access to global security markets in addition to the regulatory frameworks, and accounting profession activities, apply pressure on companies operating in the UAE to put risk-disclosure regulations into effect. Therefore, the SCA issued a new Corporate Governance Code in 2009, effective on April 30, 2010 and based on international standards aimed at improving the effectiveness of corporate governance (Bainbridge al. 2011; Halbouni et al. 2016).

Hossain and Hammami (2009) argued that confidence in financial markets is essential for users of accounting information therefore, information disclosure is a vital element to fulfill this confidence. Berger and Gleißner (2010) believed that the low level of risk disclosure could be attributed either to management preference to avoid disclosing risk for special reasons, or to the fact that management has no better information about risk. Goldstein (1998), Shirai (2001), and Berger and Gleißner (2010) argued that low-quality disclosures and transparency not only affects the amount, timing, and risk related to their investments, but also the attractiveness of their investments and the cost of capital. Shleifer and Vishny (1997) viewed risk disclosure as an indicator of the quality of corporate governance. They argued that corporate governance and risk disclosure are increasingly interrelated (Lajili, 2009; Oliveira et al., 2011; Collins et al., 2014). Mimba et al. (2007) confirmed that weak corporate governance is attributed to the lack of transparency and scarcity of information about corporations.

With reference to the impact of firms' characteristics and the level of risk disclosure, the results indicate that business type and company age have significant impacts on UAE companies' risk disclosure, while the results do not show any significant impact of audit firm, company size, profitability, leverage, and liquidity on UAE companies' risk disclosure.

The current study's results on the significant impact of business type on risk disclosure are in accordance with those obtained by Abdelsalam and Weetman (2007) and Hassan (2009), but not with those of Chirico and Baroma (2013) that business type has no significant impact on risk disclosure. The insignificant impact of company size on the level of risk disclosure is in line with the findings of Hassan (2009) and Anagnostopoulos and Gkemitzis (2013), but not with those of Amran et al. (2009), Hossain and Hammami (2009), Anagnostopoulos and Gkemitzis (2013), Chirico and Baroma (2013), Uyar et al. (2013), and Al Shammari (2014) that company size has a positive significant impact on voluntary disclosure.

Regarding the negative significant impact of company age on risk disclosure, the results of the current study are in accordance with Owusu-Ansah's (1998) argument that younger companies suffering from competitive disadvantage are motivated to disclose more information. The results obtained in this study are not in accordance with either Hossain and Hammami's (2009) findings that a positive significant association exists between company age and risk disclosure or with the findings of Alsaeed (2006) and Hossain and Reaz (2007) that company age does not have a significant impact on risk disclosure.

With reference to the impact of profitability on risk disclosure, the results of the current study reveal that neither ROA nor ROE have a significant impact on risk disclosure in the UAE. The results confirm Anagnostopoulos and Gkemitzis's (2013) findings that profitability does not have a significant impact on risk disclosure, while at the same time, the insignificant impact of leverage and liquidity on risk disclosure are not in line with Abdelsalam and Weetman's (2007) findings that leverage and liquidity have significant impacts on risk disclosure.

This study contributes to the corporate governance literature by examining risk disclosure as an "internal control mechanism" that companies can adopt to reduce risk. The study has implications for regulators, professional bodies, companies, and stakeholders, which play an essential role in corporate governance of exercising pressure on individual corporations to establish risk disclosure regulations or, as Hassan (2011) refers to, "strategic disclosure" that enables those corporations to communicate positive images to a wider range of stakeholders, especially in emerging markets seeking sustainable growth and foreign investments. The current study has a limitation in that it does not investigate the degree of compliance with IAS 21 for 2011 and 2012 for financial institutions. A future study could measure risk disclosure for periods following the effective date of July 2015 to comply with the IFRS, as required by the UAE Commercial Companies Law and Corporate Governance Code. In addition, another future study could investigate the effectiveness of corporate governance in the UAE via companies' adaptation to the requirements of the SCA. Furthermore, a future study could be conducted to investigate risk disclosure by financial institutions through measuring the degree of compliance with IFRS 7 Financial Instruments Disclosure requirements.

\section{References}

Abdelsalam, O. H., \& Weetman, P. (2007). Measuring accounting disclosure in a period of complex changes: The case of Egypt. Advances in International Accounting, 20, 75-104. 
Abraham, S., \& Cox, P. (2007). Analyzing the determinants of narrative risk information in UK FTSE 100 annual reports. The British Accounting Review, 39(3), 227-248.

Aerts, W. (2005). Picking up the pieces: Impression management in the retrospective attributional framing of accounting outcomes. Accounting, Organizations and Society, 30, 493-517.

Ahmed, K., \& Nicholls, D. (1994). The effect of non-financial company characteristics on mandatory disclosure compliance in development countries: The case of Bangladesh. The International Journal of Accounting, 29, 62-77.

Akhtaruddin, M. (2005). Corporate disclosure practices in Bangladesh. The International Journal of Accounting, 40, 399-422. http://dx.doi.org/10.1016/j.intacc.2005.09.007

Al Shammari, A. (2014). An Investigation of the Impact of Corporate Governance Mechanisms on Level of Corporate Risk Disclosure: Evidence from Kuwait. Retrieved from http://thejournalofbusiness.org/index.php/site/article/view/491

Alsaeed, K. (2006). The association between firm-specific characteristics and disclosure: The case of Saudi Arabia. Managerial Auditing Journal, 21(5), 476-496.

Amran, A., Bin, A. M. R., \& Hassan, B. C. H. M. (2009). Risk reporting: An exploratory study on risk management disclosure in Malaysian annual reports. Managerial Auditing Journal, 24(1), 39-57.

Amran, A., Manaf Rosli Bin, A., \& Che Haat Mohd Hassan, B. (2008). Risk reporting: An exploratory study on risk management disclosure in Malaysian annual reports. Managerial Auditing Journal, 24(1), 39-57.

Anagnostopoulos, Y., \& Gkemitzis, C. (2013). Size, profitability and risk level effects of accounting disclosures: A study on the Greek banking industry. Public and Municipal Finance, 2(2), 15-34.

Bainbridge, A., Kraishan, M., \& Perrin, H. (2011). Corporate Governance for UAE Companies. Retrieved from http://www.martindale.com/corporate-law/article_Norton-Rose-OR-LLP_1357400.htm

Barako, D. G., Hancock, P., \& Izan, H. (2006). Factors influencing voluntary corporate disclosure by Kenyan companies. Corporate Governance: An International Review, 14(2), 107-125.

Benston, G. (1973). Required Disclosure and Stock Market: An Evaluation of the Securities Act of 1934. American Economic Review, 132-155.

Berger, P., \& Hahn, R. (2003). The impact of SFAS no. 131 on information and monitoring. Journal of Accounting Research, 41, 163-223.

Berger, T., \& Gleißner, W. (2010). Risk Reporting and Risks Reported: A Study on German HDAX-Listed Companies 2000 to 2005.

Bradbury, M. E. (1990). The Incentives for Voluntary Audit Committee Formation. Journal of Accounting and Public Policy, 9(1), 19-36.

Cerf, A. R. (1961). Corporate Reporting and Investment Decisions. Berkeley: University of California Press.

Chirico, A., \& Baroma, B. (2013). The voluntary disclosure of financial statements Empirical evidence from the Egyptian companies. LAP LAMBERT Academic Publishing, 11-02.

Chow, C. W. (1982). The Demand for External Auditing: Size, Debt and Ownership Influences. The Accounting Review, 57(2), 272-291.

Chow, C. W., \& Wong-Boren, A. (1987). Voluntary financial disclosure by Mexican corporations. The Accounting Review, 62(3), 533-541.

Collins N. G., Lindop, S., \& Thomas, D. A. (2014) Corporate governance and risk reporting in South Africa: A study of corporate risk disclosures in the pre- and post-2007/2008 global financial crisis period. International Review of Financial Analysis (In Press). http://dx.doi.org/10.1016/j.irfa.2013. 07.001

Collins, D., \& Salatka, W. (1993). Noisy accounting earnings signal and earnings response coefficients: The case of foreign currency accounting. Contemporary Accounting Research, 10(1), 119-159.

Cooke, T. E. (1991). An Assessment of Voluntary Disclosure in the Annual Reports of Japanese Corporations. The International Journal of Accounting, 26, 174-189.

Cooke, T. E. (1992). The impact of size, stock market listing, and industry type on disclosure in the annual reports of Japanese listed corporations. Accounting \& Business Research, 22, 229-237.

Copeland, R. M., \& Frederick, W. (1968). Extent of Disclosure. Journal of Accounting Research, spring, 6(1), 
106-113.

Coy, D., \& Dixon, K. (2004). The public accountability index: Crafting a parametric disclosure index for annual reports. The British Accounting Review, 36, 79-106. Deloitte, IAS plus. Retrieved from http://www.casplus.com/pubs/files/2007checklist.pdf

Diamond, D. W. (1985). Optimal release of information by firms. Journal of Finance, 40, 1071-1094.

Dobler, M., Lajili, K., \& Ze'ghal, D. (2011). Attributes of Corporate Risk Disclosure: An International Investigation in the Manufacturing Sector. Journal of International Accounting Research, 10(2), 1-22.

Elbannan, M. A., \& Elbannan, M. A. (2015). Economic Consequences of Bank Disclosure in the Financial Statements Before and During the Financial Crisis: Evidence from Egypt. Journal of Accounting, Auditing and Finance, 30(2), 181-217.

Elzahar, H., \& Hussainey, K. (2012). Determinants of narrative risk disclosures in UK interim reports. Journal of Risk Finance, 13(2), 133-147.

Emm, E. E., Gay, G. D., \& Lin, C. M. (2007). Choices and Best Practice in Corporate Risk Management Disclosure. Journal of Applied Corporate Finance, 19, 17-28.

Entwistle, G. M. (1997). Managing disclosure: The case of research and development in knowledge-based firms. $\mathrm{PhD}$ Thesis. The University of Western Ontario, Canada.

Firth, M. (1979). The impact of size, stock market listing and auditors on voluntary disclosure in corporate annual reports. Accounting and Business Research, (Autumn), 273-280.

Firth, M. (1980). Corporate Reporting Policies Raising Finance and Firms. Abacus, June.

Firth, M. (1984). The extent of voluntary disclosure in corporate annual reports and its association with security risk measures. Applied Economics, 16(2), 269-277.

Goldstein, M. (1998). The Asian Financial Crises: Causes, Cures, and Systemic Implications, Policy Analyses in International Economics 55. Washington, D.C.: Institute for International Economics.

Gray, R., Kouhy, R., \& Lavers, S. (1995). Constructing a research database of social and environmental reporting by UK companies. Accounting, Auditing \& Accountability Journal, 8(2), 78-101.

Gray, S. J., \& Roberts, C. B. (1991). Corporates Social and Nonfinancial Disclosures. In Choi, F. D. S. (Ed.), Handbook of International Accounting. USA: John Wiley and Sons, INC.

Hakansson, N. (1981). On the politics of accounting disclosure and Management: An Analysis of Economic Incentives. Journal of Accounting Research, 19, 1-35.

Halbouni, O. N., \& Garbou, A. (2016). Corporate Governance and Information Technology in Fraud Prevention and Detection: Evidence from the UAE. Managerial Auditing Journal, 31(6/7).

Halbouni, S. S. (2009). Measurement of de Facto Harmonization in Accounting Practices between a Selective Countries in the Middle East: Jordan, Saudi Arabia and the United Arab Emirate. Jordan Journal of Business Administration, 5(1), 112-136.

Hassan, M. K. (2009). UAE corporations-specific characteristics and level of risk disclosure. Managerial Auditing Journal, 24(7), 668-687.

Hassan, M. K. (2011). UAE Risk Regulations and Disclosure In The United Arab Emirates: An Institutional Theory Analysis. Corporate Ownership and Control, 8(4).

Hossain, M., \& Hammami, H. (2009). Voluntary disclosure in the annual reports of an emerging country: The case of Qatar. Advances in Accounting, Incorporating Advances in International Accounting, 25(2), 255-265.

Hossain, M., \& Reaz, M. (2007). Determinants and characteristics of voluntary disclosure by Indian banking companies. Corporate Social Responsibility and Environmental Management Corp. Soc. Responsibility. Environment Management, 5, 274-288.

Hossain, M., Tan, L. M., \& Adams, M. (1994). Voluntary disclosure in an emerging capital market: Some empirical evidence from companies listed on the Kuala Lumpur Stock Exchange: Department of Accountancy, Massey University.

Huang, A., \& Vlady. (2012). The Accounting and Economic Effects of Currency Translation Standards: AASB 1012 vs. AASB 121. Journal of Modern Accounting and Auditing, 8(11), 1601-1610. 
IAS. (2011). International Accounting Standard 21 The Effects of Changes in Foreign Exchange Rates. Retrieved from http://ec.europa.eu/internal_market/accounting/docs/consolidated/ias21_en.pdf

Ismail, R., \& Abdul Rahman, R. (2011). Institutional Investors and Board of Directors' Monitoring Role on Risk Management Disclosure Level in Malaysia. Retrieved from http://ssrn.com/abstract=1984598

IFRS. (20015). IFRS Application around the World Jurisdictional Profile: United Arab Emirates. Retrieved from http://www.ifrs.org/Use-around-the-world/Documents/Jurisdiction-profiles/UnitedArab-Emirates-IFRS-Prof ile.pdf

Inchausti, B. G. (1997). The Influence of Company Characteristics and Accounting Regulation on Information Disclosed by Spanish Firms. The European Accounting Review, 6(1), 45-68.

Jensen, M. C., \& Meckling, W. H. (1976). Theory of the firm: Managerial behaviour, agency costs and ownership structure. Journal of Financial Economics, 3(4), 303-360.

Lajili, K. (2009). Corporate risk disclosure and corporate governance. Journal of Risk Financial Management, 2, 94-117. http://dx.doi.org/10.3390/jrfm2010094

Linsley, P. M., \& Shrives, P. J. (2000). Risk management and reporting risk in the UK. Journal of Risk, 3(1), 115-129.

Linsley, P. M., \& Shrives, P. J. (2005). Examining risk reporting in UK public companies. Journal of Risk Finance, 6(4), 292-305.

Linsley, P. M., \& Shrives, P. J. (2006). Risk reporting: A study of risk disclosures in the annual reports of UK companies. British Accounting Review, 38(4), 387-404.

Maines, L. A., Bartove, E., Fairfield, P. M., Hirst, D. E., Iannaconi, T. E., Mallet, R., \& Vincent, L. (2002). Recommendations on disclosure of non-financial performance measures. Accounting Horizons, 16(4), 353-362.

Marshall, A., \& Weetman, P. (2007). Modelling Transparency in Disclosure: The Case of Foreign Exchange Risk Management. Journal of Business Finance and Accounting, 34(5\&6), 705-739.

Meek, G. K., Roberts, C. B., \& Gray, S. J. (1995). Factors influencing voluntary annual report disclosure by U.S., U.K. and Continental European multinational corporations. Journal of International Business Studies, 26(3) 555-572.

Mimba, N. S. H., Jan van Helden, G., \& Tillema, S. (2007). Public sector performance measurement in developing countries: A literature review and research agenda. Journal of Accounting and Organizational Change, 3(3), 192-208.

Oliveira, L., Rodrigues, L. L., \& Craig, R. (2011). Risk-related disclosures by non-finance companies: Portuguese Practices and disclosure characteristics. Managerial Auditing Journal, 26(9), 817-839. http://dx.doi.org/10.1108/02686901111171466

Owusu-Ansah, S. (1998). The impact of corporate attributes on the extent of mandatory disclosure and reporting by listed companies in Zimbabwe. The International Journal of Accounting, 33, 605-631

Pinto, J. A. (2005). How comprehensive is comprehensive income: The value relevance of foreign currency translation adjustment. Journal of International Financial Management and Accounting, 16(2), 97-122.

Popova, V. (2013). Exploration of scepticism, client-specific experiences, and audit judgments. Managerial Auditing Journal, 28(2), 140-160.

Raber, R. W. (2003). The Role of Good Corporate Governance in Overseeing Risks. The Corporate Governance Advisor, 11(2), 11-16.

Scott, W. R. (1997). Financial Accounting Theory (1st ed.). USA: Prentice Hall.

Shirai, S. (2001). Searching for new regulatory frameworks for the intermediate financial structure in post-crisis Asia. Retrieved from http://fic.wharton.upenn.edu/fic/papers/01/0128.pdf

Shleifer, A., \& Vishny, R. (1997). A survey of corporate governance. Journal of Finance, 52, 737-783.

Singhvi, S., \& Desai, H. B. (1971). An Empirical Analysis of the Quality of Corporate Financial Disclosure. The Accounting Review, 46, 621-632.

Souissi, M., \& Khlif, H. (2012). Meta-analytic review of disclosure level and cost of equity capital. International Journal of Accounting and Information Management, 20(1), 49-62. 
Uyar, A., Kilic, M., \& Bayyurt, N. (2013). Association between firm characteristics and corporate voluntary (pp. 1080-1112).

Verrecchia, R. (1990). Information Quality and Discretionary Disclosure. Journal of Accounting and Economics, 12, 365-380.

Watson, A., Shrives, P., \& Marston, C. (2002). Voluntary disclosure of accounting ratios in the UK. The British Accounting Review, 34(4), 289-313.

Watson, D., \& Head, A. (1998). Corporate Finance: Principles and Practice (1st ed.). Pitman Publishing.

Watts, R. L., \& Zimmerman, J. L. (1986). Positive Accounting Theory. Englewood Cliffs, NJ: Prentice-Hall.

\section{Copyrights}

Copyright for this article is retained by the author(s), with first publication rights granted to the journal.

This is an open-access article distributed under the terms and conditions of the Creative Commons Attribution license (http://creativecommons.org/licenses/by/3.0/). 